\title{
Cuban Agriculture Before 1959: The Political and Economic Situations ${ }^{1}$
}

José Alvarez ${ }^{2}$

On October 28, 2000, U.S. President Bill Clinton signed the Trade Sanctions Reform and Export Enhancement Act (TSRA) which allowed U.S. firms to sell food and agricultural products to Cuba and other countries. However, the Cuban government did not purchase any of these products until December of 2001 following the devastating damage caused by Hurricane Michelle to important agricultural areas in November of that year.

Cuban purchases from U.S. firms amounted to $\$ 4.319$ million in 2001, \$138.635 million in 2002, and $\$ 256.9$ million in 2003. Cuba became the 35th most important food and agricultural export market for the United States in 2003, up from last (226th) in 2000. Actual purchases and pending contracts in the first-half of 2004 are at a pace to move Cuba into the top 20 most important markets of U.S. food and agricultural exports. Furthermore, because current U.S. legislation requires that all Cuban purchases from the United States must be conducted on a cash basis, the lack of credit risk associated with these sales makes Cuba one of the most attractive export markets for U.S. firms.
Anticipating changes in U.S.-Cuba trade relations, the Food and Resource Economics Department at UF/IFAS initiated a research initiative on Cuba in 1990, including a 1993 collaborative agreement with the University of Havana, which has lasted to this day. (Most of the resulting publications can be found at http://www.cubanag.ifas.ufl.edu). We reiterate that our role as investigators is to provide the best available information and analyses from which rational decisions can be made. The reports included in this series intend to address the increasing level of interest in the Cuban market for food and agricultural products among U.S. firms and to assist them in becoming more familiar with that market. The complete list of documents in this series can be found by conducting a topical search for "Cuba" at http://edis.ifas.ufl.edu, or under "Additional Information" at the end of this fact sheet.

\section{Introduction}

Cubans fought for their independence from Spain for most of the nineteenth century. Since most of the armed struggles took place in the countryside and the majority of the fighters were rural inhabitants, the

1. This is EDIS document FE479, a publication of the Department of Food and Resource Economics, Florida Cooperative Extension Service, UF/IFAS, University of Florida, Gainesville, FL. Published July 2004. Please visit the EDIS website at http://edis.ifas.ufl.edu.

The author would like to thank the University Press of Florida (http://www.upf.com) for permission to reproduce material from the book Cuba's Agricultural Sector (Alvarez, 2004).

2. José Alvarez, Professor, Department of Food and Resource Economics, Everglades Research and Education Center, Belle Glade, FL, Florida Cooperative Extension Service, UF/IFAS, University of Florida, Gainesville, FL.

The Institute of Food and Agricultural Sciences is an equal opportunity/affirmative action employer authorized to provide research, educational information and other services only to individuals and institutions that function without regard to race, color, sex, age, handicap, or national origin. For information on obtaining other extension publications, contact your county Cooperative Extension Service office. Florida Cooperative Extension Service/Institute of Food and Agricultural Sciences/University of Florida/Christine Taylor Waddill, Dean. 
agriarian issue was deeply embedded in the republic inaugurated on May 20, 1902.

What was the rural reality during the 57 years between 1902 and 1959? Answers appear at both extremes of the political spectrum, exposed and espoused by supporters and detractors of the current Cuban regime. The majority of supporters portray the pre-1959 era as a pseudo-republic controlled by U.S. imperialism through the imposition of the Platt Amendment (explained below). The consequences for Cuba's countryside included the existence of latifundia (feudal states in Spanish Latin America) dominated by U.S. firms, the supremacy of one crop (sugarcane), one main trading partner (the United States), unemployment, malnutrition, illiteracy, and every malaise derived from unrestrained capitalism in the hands of the "local puppets" of a foreign power. Most of the detractors, on the other hand, depict a completely different situation. During that same period, they argue that, while the situation was far from perfect, the economy was growing, and along with it, the economic and social status of rural inhabitants. This fact sheet intends to address these conflicting viewpoints by analyzing the available data on pre-1959 rural Cuba.

\section{The U.S. Presence}

\section{Political Background}

Almost at the end of the war of independence between Cuba and Spain, the United States intervened in what was later called the Spanish-American War of 1898. American troops occupied the island until the inauguration of the republic in 1902. One year before, U.S. Senator Orville Platt, a member of the Foreign Relations Committee, had introduced an amendment to the army appropriations bill which became law on March 2, 1901. After a long debate and enormous pressure from the U.S. government, the Cuban constitutional convention that was drafting the nation's charter accepted the Platt Amendment as an Appendix by a margin of one vote.

The eight articles of the Platt Amendment were to become at the very least a sour point in U.S.-Cuba relations for years to come. The United States was given the right to intervene in Cuba to preserve its independence and to maintain a government adequate for the protection of life, property, and individual liberty. The articles also stated that the Isle of Pines was not part of Cuba (it remained occupied by the United States), and granted the United States the right to lease lands necessary for coaling or naval stations, giving birth to the naval base in Caimanera, near the town of Guantánamo. After 32 years of controversy, abrogation of the Appendix became a reality on May 29, 1934, although the U.S. presence in Guantánamo remains to this day.

In 1985, reflecting on the 57 years of republican life, a Cuban public figure used the word atimia (loss or deterioration of status) to describe Cuba's republican existence:

An atímica $\mathrm{Cuba}$ - as defined by the Platt Amendment-permitted North American capital to flood the island due to the safeguards offered by possible U.S. intervention. Thus, North American investment inadvertently became an element of corruption as politicians from every end of the political spectrum used American influence to gain power, to retain power, and/or to engage in business with the North American banking sector (Carrillo, 1985, p. 163).

How deep was this penetration of American capital in Cuban agriculture? The next section discusses American (and other foreign) participation in Cuba's agriculture, especially sugar.

\section{Agriculture and Sugar}

In the section of his book devoted to explaining how sugar came to become the prime economic activity in Cuba, Jenks states: "Cuba had not always been a great sugar-producing country.... The sugar industry came to dominate the island chiefly in the generation from 1834 to 1867 . And during that period Cuba was the richest colony in the world" (1928, p. 21). This quote is important for three reasons. First, it is clear that the monoculture in Cuba's countryside was not the result of mostly U.S. capital investments since the process had occurred several decades before the 1898 American intervention. Second, sugar was not always tied to the list of miseries usually attributed to the crop. Finally, one year after the process of consolidating the sugar industry had 
ended, the people of Cuba started their first war of independence against Spain (1868-1878) under the leadership of rich owners of sugar mills and plantations.

The real revolution in Cuba's sugar industry, however, came between 1878 and 1898, right after the first war of independence against Spain (also known as the 10-year war). Jenks believes that "the revolution was reflected in sharp declines in price which made it necessary for Cuba to produce more cheaply and efficiently and to transform her economic society to do so" (1928, p. 27). After the end of the 10-year war American investors took advantage of deteriorating economic conditions to take over estates they had tried unsuccessfully to buy before while others acquired properties at very low prices. The second type of investment was directed towards virgin soil. As a result, many new sugar plantations and mining operations were developed (Jenks, 1928, pp. $33,34,35)$.

The total amount of investment, however, was not large. Jenks lists U.S. investments in Cuba before 1894 at $\$ 50$ million; between 1898 and 1902 (the period of the first U.S. intervention) at $\$ 30$ million; and between 1902 and 1906 at $\$ 80$ million. Of the $\$ 160$ million invested up to $1906, \$ 30$ million, or $18.7 \%$, was in the sugar industry. Total investments in agriculture (sugar, tobacco, fruit, and cattle) amounted to $\$ 96$ million, or $60 \%$ of the total. The U.S. investments during the 1909-1913 period were estimated at \$205 million. Sugar accounted for $\$ 50$ million, or a $24.4 \%$ share, while agriculture in general received another $\$ 10$ million (1928, pp. 162-163, 165).

The first world war began in Europe in 1914, with the United States joining the effort on April 6, 1917, and Cuba shortly thereafter. As Jenks has put it, "sugar and geography made Cuba a participant in the [first] World War," and Cuba's main role was producing and marketing sugar (1928, pp. 193, 194, 196).

Production instabilities and marketing problems with Cuban sugar were the pretexts for the United States to enter the sugar business in 1918. In effect: "The preponderant position of sugar in Cuban economic life, the increased output, the extension of mills and plantings, the new intimacy of American bankers with Cuban opportunities, and the temporary interruption of the competitive sugar market by the action of the United States were prominent factors in the social history of Cuba in the years that followed the Peace" (Jenks, 1928, p. 205).

American financial interests continued investing in Cuba until 1959. Data from the U.S. Department of Commerce (Prensa Latina, 1960) show the magnitude and distribution of U.S. direct investment in Cuba for the years 1929, 1943, 1950, 1953, and 1958. Overall investments show a declining trend. Investments in agriculture, including the sugar industry, show a sharp decline from 1929 to 1943 and some stability afterwards. However, in terms of relative shares, investments in agriculture declined from $67 \%$ in 1929 to $26.5 \%$ in 1958 . Extremely poor activity in the manufacturing sector contrasts with an increasing trend in mining investments. By 1958, investments in agriculture were back to $\$ 265$ million although they represented only around $26 \%$ of total U.S. investments (Valdés Paz, 1997, p. 16).

The decreasing importance of U.S. investments in the Cuban sugar industry from 1939 to 1950, along with the relationship with domestic and other foreign investors, is explained in IBRD (1951, p. 821). In 1939, U.S. investors owned 68 of the 176 existing mills and 55\% of total production. By 1950, they owned 44 of the 161 mills and slightly over $47 \%$ of total output. Cuban nationals were the proprietors of 56 mills in 1939 and of 108 mills in 1950, and their share of total output increased from $22.4 \%$ in 1939 to $49.5 \%$ in 1950 . Of the remaining countries with a presence in Cuba's sugar industry in 1939 (Spain, Canada, England, Holland, and France), investors from Canada and England had sold their properties by 1950, and investors from Spain, Holland, and France had greatly reduced their properties in Cuba.

The decline in importance of foreign interests, according to IBRD (1951, p. 821), was the result, among other factors, of labor and management problems and lower profits. According to Thomas (1971, p. 1147), the decline had started by 1930 and was occasioned by labor problems and restrictions on expansion due to the policy of Cubanization and the Sugar Coordination Law of 1937 (EDIS FE480), 
which favored the independent growers over the mill owners. Sales of U.S. mills started in 1934.

American investments in Cuba, estimated at \$1 billion at the time of Batista's overthrow on January 1, 1959, were also important in other branches of the economy. The U.S. selective investment in Cuba gave rise to what Thomas calls a "reserve country" in many ways, which was clearly infuriating to the Cubans. And he adds:

The mines were only worked when North America was waging a war. Peace brought inactivity. It was the same story as in the sugar industry. U.S. ownership of the mineral fields meant that the Cuban economy could never be seen as a whole. Even those minerals which were exported were left unprocessed.... The importance of Cuba to the U.S. will not be fully understood without realizing that the U.S. companies engaged in Cuba read like the Who's Who of American business: total U.S. investment stood at $\$ 1$ billion; shareholding and commercial-political interest was widespread. Any action in Cuba which affected these interests would be bound to have widespread consequences. 160,000 workers, over $90 \%$ of Cubans, were employed in North American firms in Cuba, and North American firms spent \$M730 in Cuba, of which $\$$ M70 was in taxes-almost $20 \%$ of the Cuban budget. Many of these firms were Cuban subsidiaries of U.S. companies, dependent on the parent company for supplies. Any radical party in Cuba would have been driven to affect these interests since the U.S. business community dominated Cuban trade... (1971, pp. 1171-1172).

This picture may seem exaggerated to those who praise pre-1959 Cuba. The U.S. influence, however, was only part of the total situation, as will be seen in the following sections of this fact sheet.

\section{Agricultural Economic Variables}

The previous section discussed the political and agricultural U.S. presence in Cuba since colonial times. The variables considered under this heading, however, concentrate on the period between the mid-1940s and the triumph of the revolution in 1959, excluding the colonial period and first decades of the republic, for two reasons. First, this is not a study on Cuban agricultural history. Second, the existence of the 1946 Agricultural Census and the 1953

Population, Housing, and Electoral Census allows us to compare changes during that period.

\section{Land Use, Tenure, and Structure}

The 1946 Cuban agricultural census provides a general picture of the land situation in Cuba (IBDR, 1951, p. 87). Of the total land area of approximately 11.5 million hectares, close to $79 \%$ was considered as land in farms. The land in farms was distributed as follows: $21.7 \%$ was cultivated, $42.9 \%$ was in pastures, and $13.9 \%$ consisted of woods. In addition, $3 \%$ was covered by a damaging weed (marabú), $18.2 \%$ was devoted to other uses (roads, buildings, and unproductive land), and $0.3 \%$ was idle or uncultivated farms. There were 160,000 farms with an average farm size of 56.7 hectares (IBDR, 1951, p. 87).

Changes in farm size between 1946 and 1959 can also be compared. The 1946 Agricultural Census lists 62,500 farms with 9.9 or less hectares, accounting for $39 \%$ of all farms, or about $3.2 \%$ of total area. At the upper extreme, the Census counted 2,336 farms with 500 hectares or more (including 114 farms with over 5,000 hectares), accounting for $1.4 \%$ of all farms, or $47 \%$ of the total area (IBDR, 1951, p. 88).

The comparisons between 1946 and 1959 show two irrefutable facts about pre-1959 Cuban agriculture. First, both latifundia and minifundia, so damaging for agricultural development, coexisted side by side. Second, agricultural land ownership had become even more concentrated in the period that preceded the revolution. While in 1946 about $8 \%$ of the farms were 100 hectares or more in size, by early 1959 the same percentage of farms had 402.7 or more hectares.

The existence of latifundia was a clear violation of the 1940 Cuban Constitution. Article 90 stated that latifundia was proscribed and that, in order to eliminate it, the law would determine the maximum amount of land that every person or entity could possess for each type of agricultural activity. It also 
stated that the law would limit the acquisition and possession of land by foreign persons and companies and would take measures aimed at returning the land to Cubans (Constitución, 1940, p. 28).

With regard to specific crops, the 1946 Agricultural Census classified farms according to their principal source of income. Sugarcane farms dominated in terms of total income, share of income from main crop, total number of farms, and share of total farms. Those with livestock and livestock products as their main source of income followed behind sugarcane farms, except for total income. Tobacco, vegetables, and cereal and legume crops were also important. The statistics for the remaining products (coffee, fruits from trees, forests, and other) denote a smaller importance (IBRD, 1951, p. 89).

When analyzing the period preceding the 1950s, the International Bank for Reconstruction and Development said:

Sugar is not only Cuba's principal source of livelihood. It dominates the economy-and the outlook of the people-in various ways. Sugar plays an even greater part in the exports of Cuba today than it did in the past. The economy, in fact, is more at the mercy of the fluctuations in world sugar prices than ever before. This causes constant feelings of insecurity, which in turn diminish business confidence and tend to restrict initiative. When sugar prices are good, no other activity in Cuba is so rewarding. But, when they are bad-since the economy hinges on sugar-most other activities suffer at the same time. To many Cuban investors, therefore, other forms of investment seem less attractive than sugar in good times and almost as risky in bad. Hence a "vicious circle": only greater diversification can reduce Cuba's dependence on sugar but the dominance of sugar discourages diversification (IBRD, 1951, p. 7).

\section{Diversification and Productivity}

The absence of farm diversification was an important characteristic of the Cuban agricultural sector before the 1959 revolution. To a great extent, individual farms were dedicated to one crop. The data above have already established the existence of monoculture with the predominance of sugarcane. The one-crop dominance, however, was not only true in sugarcane but also in tobacco farms, cattle ranches, and coffee plantations to mention just a few.

Land productivity, expressed in terms of average value of production per hectare, was estimated for three farm sizes in the 1946 Agricultural Census. Average values of production for farms with up to 10 hectares were calculated to range between 102 and 200 pesos, farms with more than 1,000 hectares were estimated at 23.8 pesos, and farms with over 5,000 hectares were estimated at 4.94 pesos (Valdés Paz, 1997, p. 29). Productivity per area was, therefore, much lower for large farms than for small farms.

A more balanced agricultural production was obviously needed. According to the Mission of the IBRD (1951, pp. 94-96), the 10 major factors that served as impediments to the fulfillment of that goal were:

- History: Cuba grew rich as the sugar supplier of the world during several phases of her history. That fact resulted in attitudes and land use patterns that favored sugarcane in Cuba for a long time.

- Capital: Using modern agricultural techniques for the production of other crops is not possible because capital is in the hands of sugarcane producers. Those engaged in the production of other crops have the most difficulty in attracting capital.

- Technology: Agricultural knowledge and technology are in the hands of sugarcane producers and processors. No governmental efforts are aimed to encourage growing alternative crops.

- Ease: Sugarcane, especially in Cuba, is an easy crop to grow. Several harvests are obtained from the plant crop, and compared with other crops it requires little work.

- Credit: It is granted mostly for sugar production and to a lesser extent for tobacco. Data for 1940, for example, show that while the sugar industry received $43.1 \%$ of all bank loans, the remaining 
agricultural activities only received $1.7 \%$ (Zuaznábar, 1986, p. 121). That situation, however, changed somewhat after the creation of the Banco de Fomento Agrícola e Industrial de Cuba (Agricultural and Industrial Development Bank of Cuba, BANFAIC) during the 1950s (EDIS FE480).

- Roads: Sugar has its own private railroad network connected with the public rail system and the ports. Other crops would need farm-to-market roads that are nonexistent.

- Marketing: Almost all marketing facilities have been built for sugar. Growers of many other crops face a more disorganized market and abuses by unregulated intermediaries.

- Price Uncertainties: Sugar prices for Cuba are generally very stable because of large purchases associated with international agreements. Day-to-day price variations for most other crops are the rule.

- Governmental Controls: Sugar gets the most assistance from government in receiving the best price. Most other commodities receive the opposite treatment because of governmental action to lower their cost to consumers.

- Freight Rates: Discriminatory rates, at least until recently, have favored sugar.

With these factors working against crop diversification, it is almost impossible to add other dominant crops to the sugar economy. Therefore, sugarcane production and sugar processing were going to predominate in the Cuban economy for years to come.

\section{Foreign Trade}

According to the IBRD, "few countries are so dependent on international trade as Cuba. In fact, unless it is realized to what extent the island is a one-crop export economy, it is impossible to understand the basic problems of further economic development" (1951, p. 723). Whatever period one selects to study the structure of Cuba's foreign trade before 1959, the same results are obtained: exports were dominated by sugar and its byproducts. For example, from 1920 through 1949, Cuban exports showed sugar's preponderance, followed by tobacco products (IBRD, 1951, p. 801). That situation did not changed until 1959.

A more detailed breakdown of exports and imports for the 1940-1949 period shows more insights (IBRD, 1951, p. 742). Almost the totality of Cuba's exports was agricultural commodities. Sugar and its derivatives were the dominant exports while food and beverages were the dominant imports. The results of simple linear regression analyses show exports increasing at an annual average rate of $\$ 62.1$ million during the 1940-1949 period while the annual average growth rate for imports was $\$ 48.63$ million.

According to the IBRD (1951, pp. 723-724, 727), the importance of exports was striking, even for a small country, directly as a source of income and employment and indirectly as the main influence on overall economic activity. During most of the 1940-1949 period, exports accounted for about one-third of the gross national product and around $40 \%$ of the national income, the latter percentage being the highest for economies of similar size and structure. The disadvantages of depending so heavily on exports included, among others, revenue instability and Cuba's inability to control sugar quota restrictions, foreign tariffs, changes in tastes, economic fluctuations, and wars in the outside world to which her economic fate was tied.

Not only was Cuba's foreign trade dominated by exports, and exports dominated by sugar, but the predominant buyer and seller was the United States. Most of the sugar exports went to the United States, with the same being true for unmanufactured tobacco and coffee exports. In addition, Cuba exported considerable quantities of vegetables from 1924-1925 through 1940-1941 (Minneman, 1942, pp. 77, 81, 86). However, as stated by Minneman, U.S. imports of Cuban vegetables were "highly seasonal and limited to the winter and early spring months when field production is not possible in most of the United States.... Furthermore, imports from Cuba are only for consumption as fresh vegetables, whereas much of the domestic crop in the United States is grown for canning" (1942, p. 81). Most fruit exports from Cuba during the 1926-1940 period also went to the 
United States (1942, p. 61). The United States was practically the only seller of fruits to Cuba during the same time period $(1942$, p. 76$)$.

Despite the preponderant role of the United States in Cuba's foreign trade, the overall value of Cuban exports to the United States surpassed her imports throughout the 1950s. Cuba's exports amounted to $\$ 780.4$ million while her imports only reached \$277.4 million. While there was no preponderant commodity imported by Cuba from the United States, sugar was by far the dominant commodity in Cuba's exports to the United States (Wylie, 1969, p. 27).

With no other country did the United States have as close an economic relations as with Cuba; it was the only country with which the United States had a reciprocity treaty involving exclusive preferential tariff treatment. At the outset of the republic, under the Treaty of Commercial Reciprocity of 1902, the United States granted Cuba exclusive tariff reductions of $20 \%$ below the rates to other countries on all dutiable commodities. Tariff reductions of $30 \%$ and $40 \%$ were granted on wheat flour and rice, respectively, from the United States. This treaty basically explains the dominant role of the United States in Cuba's exports and imports. Some tariff rates were increased by Cuba in 1927 to protect and encourage domestic industries. Trade with the United States was greatly improved as a result of the enactment of a new reciprocal trade agreement in 1934. Under this agreement, Cuba extended preferential tariff treatment to more than 400 American items, with preferences ranging from $20 \%$ to $60 \%$. Concessions to Cuba were granted to 35 items, increasing the preferential tariff rate in some cases up to $50 \%$. Further agreements increased concessions in 1939 and 1942 (Minneman, 1969).

The case of sugar in U.S.-Cuba trade deserves special attention. As shown above, sugar was the main Cuban export to the United States. Until 1960, Cuba provided over one-third of the total U.S. sugar requirements, playing the role of an "ever-normal granary" for U.S. sugar needs. One aspect of the preferential treatment it received in return is contained in the Sugar Act of 1948, which allocated to Cuba an import quota equivalent to $98.64 \%$ of the difference between U.S. consumption requirements and the sum of the fixed tonnage quotas for the domestic areas and the Philippines, with the remaining $1.36 \%$ going to other foreign countries. Thus, this arrangement allocated nearly all of the increases in U.S. consumption requirements to Cuba. The 1951 amendment to the Sugar Act set Cuba's share at $96 \%$. The 1956 amendment enabled domestic producers to participate in the growth of the U.S. market; that is, any growth in U.S. consumption beyond 8.35 million short tons was shared $55 \%$ by domestic areas and $45 \%$ by foreign countries (Bates, 1968, p. 522). The July 1960 amendment to the Sugar Act provided for presidential actions under which import quotas from Cuba were suspended.

\section{References}

Alvarez, José. 2004. Cuba's Agricultural Sector. Gainesville, FL: University Press of Florida.

Bates, Thomas H. 1968. The Long-Run Efficiency of United States Sugar Policy. Journal of Farm Economics 50: 521-535.

Carrillo, Justo. 1985. Vision and Revision: U.S.-Cuban Relations, 1902 to 1959. In Cuba: Continuity and Change, edited by J. Suchliki, A. Jorge, and D. Fernández, pp. 163-174. Miami, FL: University of Miami.

Constitución de la República de Cuba. 1940. La Habana: Editorial Páginas.

IBRD. International Bank for Reconstruction and Development. 1951. Report on Cuba. Washington, DC.

Jenks, Leland H. 1928. Our Cuban Colony-A Study in Sugar. New York, NY: Vanguard Press.

Minneman, P.G. 1942. The Agriculture of Cuba, Foreign Agricultural Bulletin No. 2, United States Department of Agriculture, Washington, DC (December).

Prensa Latina. 1960. Panorama Económico Latinoamericano. La Habana.

Thomas, Hugh. 1971. Cuba: The Pursuit of Freedom. New York, NY: Harper \& Row. 
Valdés Paz, Juan. 1997. Procesos Agrarios en

Cuba, 1959-1995. La Habana: Editorial de Ciencias

Sociales.

Wylie, Kathryn H. 1969. A Survey of Agriculture

in Cuba. ERS-Foreign 268, U.S. Department of

Agriculture, Washington, DC (June).

\section{Additional Information}

Below is a list of the fact sheets in this series on

Cuban Agriculture. They can be accessed by clicking on the highlighted links:

- FE479 - Cuban Agriculture Before 1959: The Political and Economic Situations

- FE480 - Cuban Agriculture Before 1959: The Social Situation

- FE481 - Transformations in Cuban Agriculture After 1959

- FE482 - Overview of Cuba's Food Rationing System

- FE483 — The Issue of Food Security in Cuba

- FE484 - Acopio: Cuba's State Procurement and Distribution Agency

- FE485 - Antecedents of the Cuban Agricultural Policies of the 1990s

- FE486 - Chronology of Cuban Reform Policies with Emphasis on Agriculture, 1993-1995

- FE487 - Cuba's Basic Units of Cooperative Production

- FE488 - Cuba's Agricultural Markets

- FE489 - Environmental Deterioration and Conservation in Cuban Agriculture

- FE490 - The Potential Correlation between Natural Disasters and Cuba's Agricultural Performance 